Thameem, M., Rybkowski, Z. K., and Smith, J. P. (2017). "Delivery Methods and Social Network Analysis of Unethical Behavior in the Construction Industry.” In: LC3 2017 Volume II - Proceedings of the 25th Annual Conference of the International Group for Lean Construction (IGLC), Walsh, K., Sacks, R., Brilakis, I. (eds.), Heraklion, Greece, pp. 453-461. DOI: https://doi.org/10.24928/2017/0213

\title{
DELIVERY METHODS AND SOCIAL NETWORK ANALYSIS OF UNETHICAL BEHAVIOR IN THE CONSTRUCTION INDUSTRY
}

\author{
Muzafar Thameem ${ }^{1}$, Zofia K. Rybkowski ${ }^{2}$, and James P. Smith ${ }^{3}$
}

\begin{abstract}
The construction industry accounts for about one-third of gross capital formation and is ranked as one of the most corrupt. It is a multifaceted industry with unregulated transactions in which illicit behavior can be difficult to detect. The effects of corruption go beyond demoralization associated with bribery, it can lead to substandard quality of infrastructure and insufficient funds available for project maintenance. There are a multitude of reasons identified as possible causes for unethical conduct. A few researchers cited corruption as a result of an unethical decision. Prior research concerning corruption in construction has called for several main strategies: enhanced transparency, ethical codes, project governance, and audit and information technology. However, strategies to combat corruption may not be sufficient. This research first presents an overview of unethical conduct in the industry. Then it examines the ethics in the industry followed by types of relationships and their structure which may be conducive to unethical conduct within the framework of different delivery methods. Finally, an argument is made regarding the importance of strength of relationships in curbing unethical conduct.
\end{abstract}

Keywords: Unethical behavior, Relational Contracting, Lean Construction

\section{INTRODUCTION}

\subsection{Corruption in Construction}

Corruption in construction is associated with economic growth and stages of development (Ehrlich and Lui 1999). It is considered a major hurdle to economic and social development. It is estimated that the annual loss from corruption in the global construction market accounts for $10 \%$ of global construction market value (Sohail and Cavill 2008).

Unethical decisions may occur at any phase during a project: initiation, planning and design, bidding and construction, and operation and maintenance (Tabish and Jha 2011). Ahmad et al. (1995) and Kenny (2009) suggest that construction observes widespread unethical behavior mainly due to the fragmented nature of the industry.

Le et al. (2014) identified twelve forms of corruption in the industry: bribery, fraud, bid rigging, embezzlement, kickback, conflict of interest, dishonesty, unfair conduct, extortion, negligence, front companies, and nepotism (Table 1).

\footnotetext{
${ }^{1}$ Graduate Student, Department of Construction Science, College of Architecture, Texas A\&M University, College Station, Texas, USA, muztheem@tamu.edu

${ }^{2}$ Associate Professor, Department of Construction Science, College of Architecture, Texas A\&M University, College Station, Texas, USA, Ph :+1-979-845-4354, zrybkowski@tamu.edu

${ }^{3}$ Assistant Professor, School of Technology, Department of Construction and Facilities Management, Brigham Young University, Provo, UT, USA, james_smith@byu.edu
} 


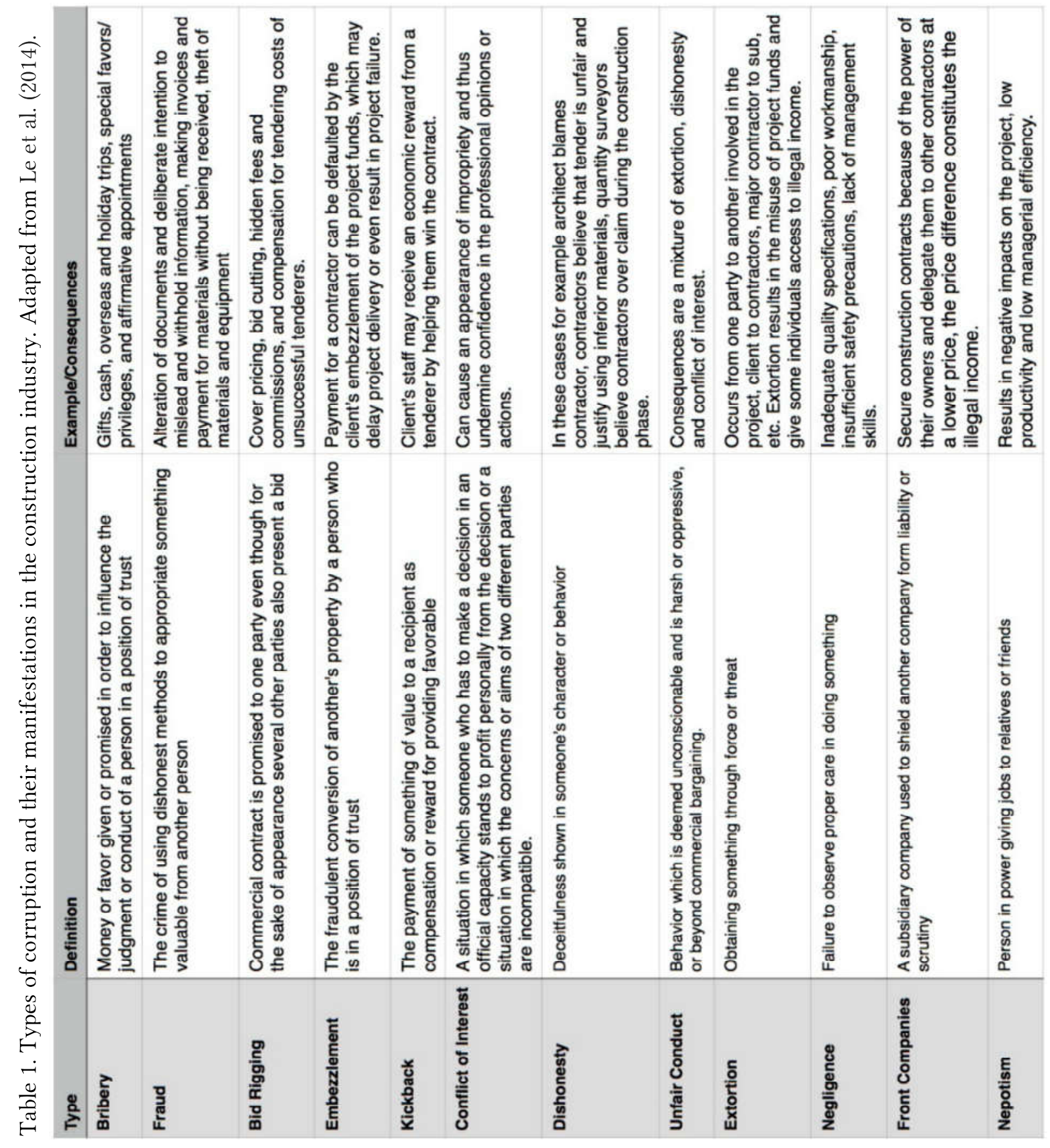

Corruption can hinder the social and economic development of societies worldwide (Snaith and Khan 2008). So far anti-corruption strategies involve recommendations for enhanced transparency, ethical codes, project governance, auditing, and information technology (Le et al. 2014). But despite these, the severity of corruption has not been alleviated, and construction remains corrupt (Transparency International 2002, 2006, 2008, 2011). The primary causes identified are: excessive competition in the tendering process, insufficient transparency in selection criteria during tendering, inappropriate political interference in cost decisions, the complexity of institutional roles 
and functions, and asymmetrical information among parties (Le et al. 2014). Several researchers have argued that unethical behavior is one of the causes of corruption in the industry (ZarkadaFraser and Skitmore 2000; Moodley et al. 2008). In this paper, we focus on unethical behavior as other issues such as asymmetric information and transparency have been studied extensively.

\subsection{Ethics in the Construction Industry}

Although employers may not force their employees to initiate or participate in unethical conduct, stakeholders in the construction industry witness or experience unethical conduct to some degree in the form of unfair conduct, negligence, conflict of interest, collusive tendering, fraud, confidentiality and propriety breach, bribery and violation of environmental ethics (Vee and Skitmore 2003). Workers do enjoy a fundamental right of professional conscience (Martin and Schinzinger 1996). However, it has been observed that in general, professionals tend to believe their obligations to the client are more important than to others, such as the public (Johnson 1991).

In the US construction industry, architects possess high ethical standards (Abramowitz 1998; Pressman 1997) which can be traced back to the American Institute of Architect's code of ethics which prescribes "the common good is right" for issues not governed by laws (Pressman 1997). Similarly, the Project Management Institute (PMI: Code of Ethics and Professional Conduct, n.d.) lays down a code of ethics for project managers and the American Institute of Constructors (AIC: Bylaws and Code of Ethics, n.d.). However, contractors have developed a sour reputation for unethical behavior; this may be attributed to the high level of disputes between parties during a project (Pilvang and Sutherland 1998). Another major contributor to this may be the influx of new construction companies that lack necessary skills combined with greed (Ritchey 1990).

Several organizations have access to ethical conduct guidelines to assist with the decisionmaking process, but the construction industry still suffers from unethical conduct (Vee and Skitmore 2003). Advancement in ethics in the construction industry depends on the implementation of ethical guidelines-- policies of companies combined with leadership in public-sector procurement agencies (Vee and Skitmore 2003). All participants in the industry, irrespective of guidelines, require an understanding of the meaning of "common good." Without guidelines, even ethically sound individuals have a difficult time maintaining moral standards (Vee and Skitmore 2003).

\subsection{Professional Ethics}

Professionals are defined as a group of individuals organized to serve specialized knowledge in the interest of society (Appelbaum and Lawton 1990). Johnson (1991) states that professionals are not exempt from ethical behavior, duties, and responsibilities that are binding for the common man. He adds that professionals are usually bound by principles and attitudes that control the way a profession is carried out. Johnson also argues that fairness should be extended not only for the benefit of clients but also for the greater good of society.

\section{RELATIONSHIPS AND UNETHICAL BEHAVIOR}

Previous research into unethical conduct in the construction industry has called for increasing transparency and introducing a code of ethics among other strategies. However, there is little to no research on the nature and type of relationships which may be conducive to unethical conduct. Since construction relies heavily on the dynamics of human relationships, one should consider how these relationships offer the potential to reduce unethical behavior in the industry (Hollingsworth 2016). Unethical behavior is a social phenomenon; it involves relationships between people and a 
general consideration for the "other." In the following sections, the basic types of relationships found on typical construction projects are examined.

\subsection{Types of Relationships}

The strength of a relationship is defined by the frequency, reciprocity and emotional intensity of the relationship (Granovetter 1973). A weak relationship has a low barrier to unethical conduct while in a strong relationship, the associated costs are high for unethical conduct.

The degree to which two individuals are connected in more than one way is known as multiplexity of the relationship. Multiplexity adds an additional constraint for acting unethically (Brass et al. 1998).

Unethical behavior is most likely to occur in asymmetrical relationships when the trust and emotional involvement of one individual are not reciprocated by the other (Carley and Krackhardt 1990). Asymmetrical ties place one party at an advantage and increase the opportunity and payoffs for that party.

Status is defined as the relative power difference between actors. Asymmetric power in a relationship places the party of lower status at risk of being treated unethically. The lower status party is less likely to engage in unethical conduct as the party with the upper hand can retaliate with more severe consequences. In this situation, the probability of the party with higher status engaging in unethical conduct depends almost entirely on its moral character (Brass et al. 1998).

\subsection{Structure of Relationships}

The presence of individuals in a strict hierarchal structure found in traditional delivery methods (Figure 1) increases the opportunity for unethical behavior (Zey-Ferrell and Ferrell 1982). A hierarchically flat organization increases surveillance and the reputation of the individual is put at risk. McCabe and Trevino (1993) found that ethical behavior is influenced by the individual's perception of being caught. The presence of peers, their perceptions, and frequency of contact influences ethical behavior (Izraeli 1988; McCabe and Trevino 1993; Zey-Ferrell \& Ferrell 1982; Zey-Ferrell et al. 1979). Of greater importance is the structure of the relationship. The following examines the basics of structure in a relationship.

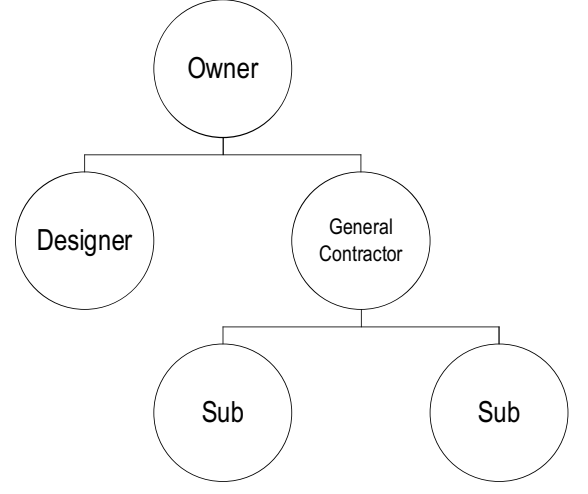

(a) Design Bid Build

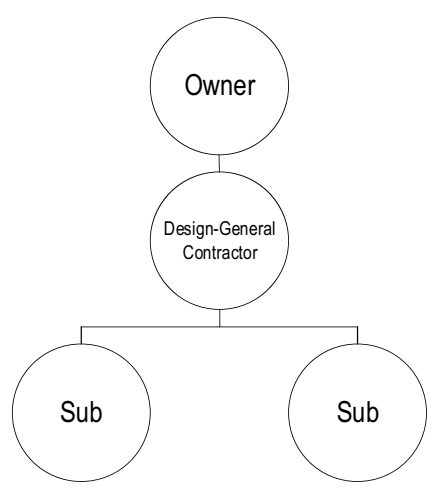

(b) Design Build

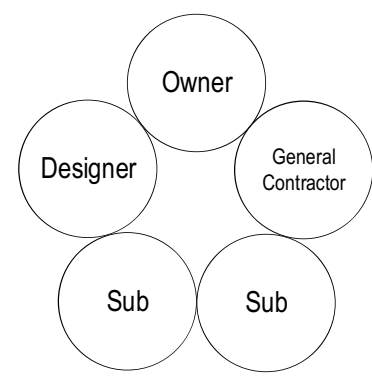

(c) Integrated Project Delivery

Figure 1. Structure of contractual relationships in different delivery methods. Adapted from El Asmar et al. 2013)

Structural holes represent the absence of a link between two individuals or parties (Burt 1992). It is the absence of a relationship and is a hindrance to information sharing. In Design Bid Build 
(Figure 1(a)), the owner, architect, and contractor may form a structure similar to Figure 2(a). There is a clear gap in communication; such relations in the industry, for example, can lead to an increase in the number of requests for information (RFIs) (El Asmar et al. 2013). The number of RFIs can be considered as a communication performance metric; they contribute to considerable waste on a project. In such situations, surveillance between parties is low and the probability of unethical conduct is high.

When participants are connected in mixed structures such as in figure $2(\mathrm{~b})$, it is less likely that actors $\mathrm{A}$ and $\mathrm{B}$ will act unethically toward one another because surveillance is higher. This relationship structure is, arguably, found in Design Build projects (Figure 2(b)). An empirical study by Hale et al. (2009) found Design Build to be superior to Design Bid Build because it facilitates greater levels of collaboration. Fewer contingencies were observed and relationships between participants were stronger.

However, in 2(b) although there is a reduced risk of unethical behavior between parties A \& B-because of increased surveillance and risk of damaged reputation--A and B can still form a coalition and act unethically toward C (Murnighan \& Brass 1991). Such coalitions have been observed in Design Bid Build and Design Build projects. Moreover, C might perceive unethical behavior even though $\mathrm{A}$ and $\mathrm{B}$ do not have any such intention. In this case, the fear of being taken advantage of--or in other words, the mere fear of unethical conduct--may become a motivating factor for $\mathrm{C}$ to engage in unethical conduct.

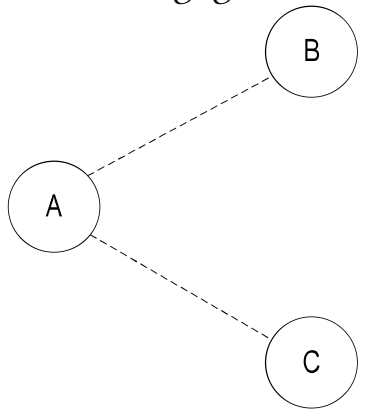

(a) Structural Hole

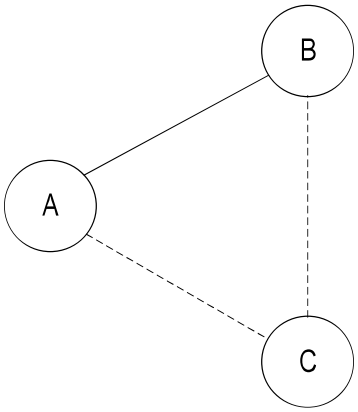

(b) Mixed

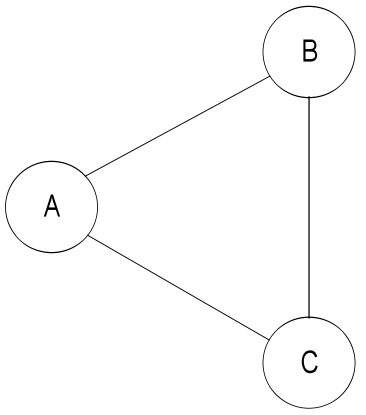

(c) Simmelian Tie

Figure 2. Relationships and unethical behavior. Adapted from Brass et al. (1998).

By contrast, Lean-Integrated Project Delivery aims to form structures between participants similar to figure 2(c). This arrangement is called a simmelian triad (Krackhardt 1999). In this instance, any noted unethical behavior is transmitted quickly to a third party as surveillance is high and there is a risk of loss of reputation.

The extent to which an individual can reach to others in the least number of links within the network is defined as centrality (Freeman et al. 1979). Direct connections increase surveillance and determine the extent to which news of unethical conduct spreads to others. Hence, actors having high centrality have more to lose from unethical conduct than those who are isolated in the network (Brass et al. 1998). Density refers to the extent of network ties as opposed to the total number of possible connections (Scott 1991). High-density networks have higher surveillance and high loss of reputation. Conversely, loosely connected ties have the potential to facilitate unethical conduct (Brass et al. 1998).

\footnotetext{
${ }^{4}$ Two people are "Simmelian tied" to each other if they are reciprocally and strongly tied to each other and if they are reciprocally and strongly tied to at least one third party in common (Krackhardt 1999).
} 
Comparing the structure of delivery methods and structure of unethical behavior from a social network analysis perspective, the similarity is striking. While it is hard to quantify the amount of unethical conduct in different delivery methods, a more collaborative approach would lead arguably lead to more ethical behavior as suggested by social network analysis of unethical behavior (Figure 3).

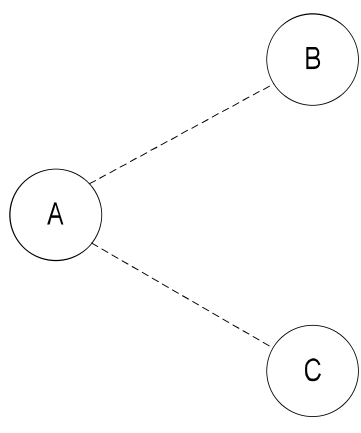

(a) Design Bid Build

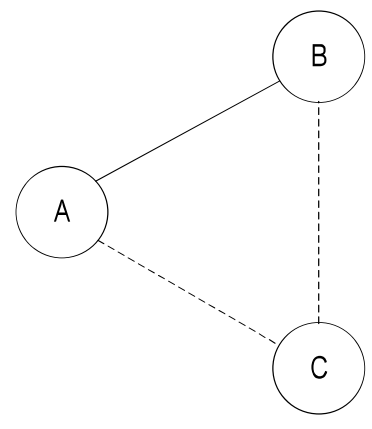

(b) Design-Bid

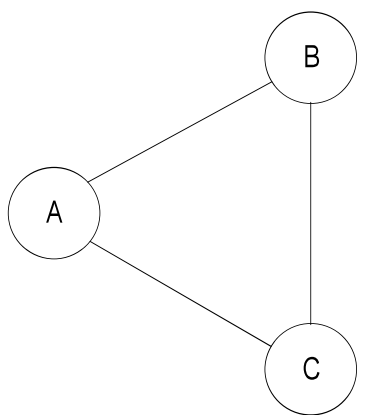

(c) Integrated Project Delivery (Simmelian Tie)

Figure 3. Comparison of structure of delivery methods and structure of unethical behavior from social network analysis perspective. Adapted from El Asmar et al. (2013) and Brass et al. (1998).

\section{LEAN CONSTRUCTION AND RELATIONAL CONTRACTING}

There are two fundamentally different types of contracting: transactional and relational (Williamson 1979; Macneil 1973). Lean construction champions the latter, as it is consistent with flow and value generation. Murdoch and Hughes (2002) state the risks associated with executing a project and to which participants are subject are considered separate while risks associated with processes are ignored in traditional delivery methods. The dispute record of the construction industry suggests it is impossible to draft traditional contracts for projects that include all contingencies and risks, limit opportunistic behavior, and still maintain efficiency (Matthews and Howell 2005). A relational contract provides a basis for long-term complex contracts with flexibility so that the participants can express their concerns in new environments (Joskow 1987, 1990; Leffler and Ruker 1991, Gundlach and Achrol 1993, Swierczek 1994).

The main characteristics of relational contracts are (Cheung et al. 2006):

- personal interactions are crucial;

- the transaction is usually of long duration;

- the future cooperation opportunity is large;

- there is flexibility to cope with unforeseen circumstances; and

- it is anti-discrete.

Relational contracts can be effective in attaining mutual benefits, developing long-term relationships and avoiding adversarial tendencies. Relational contracting enhances the project performance by sustaining long-term relationships, acting as a buffer to unethical conduct. The idea is to create value beyond the project for participants and society. Trust and partnership are held in high regard among the project participants rather than the terms of the contract. This results in greater commercial value to participants and effective collaboration through knowledge-sharing. 


\section{CONCLUSION}

In lean construction, each representative of a party is present in the Big Room. Lean construction champions a decentralized decision-making process that helps avoid the perception of being used unethically by another party. It operates on the principle of reliable workflow and metrics describing inputs to these flows are made transparent (Howell et al. 2010). By creating this kind of network, the entire team begins to think alike which sets in motion a snowball effect. This alignment resides at the crux of lean thinking. This model creates a "virtual company" with representatives from each organization who possess strong ties within their company and who share proximity with other representatives (Thomsen et al. 2010). Individuals identify and adopt similar attitudes and behavior with others who occupy similar positions in and across groups. This develops empathy toward others, acting as a barrier to unethical conduct. In this way, behavior on a Lean construction jobsite can exceed the ethical codes prescribed. This can represent a necessary step in the right direction to reduce unethical conduct in the construction industry. The structure of delivery methods shares a structure of relationship similar to that of unethical conduct from a social network analysis perspective. Construction directly reflects the economic development of a country. Implementation of Lean-IPD in construction may be an effective grass roots weapon for combatting corruption. Further research needs to be conducted through the lens of psychology to better understand the interplay of relationships and their impact on decision-making behavior within various construction delivery methods.

\section{REFERENCES}

Abramowitz, A.J. (1998). "Speak out: a lawyer finds that architects, in their intense pursuit often ethics, often deny themselves a pragmatic practice," Architectural Record, Nov, 24-7.

Ahmad, I. U., Russell, J. S., \& Abou-Zeid, A. (1995). "Information technology (IT) and integration in the construction industry," Construction Management and Economics, 13(2), 163-171.

Appelbaum, D., Lawton, S.V. (1990). Ethics and the professions, Prentice-Hall, USA

Brass, D. J., Butterfield, K. D., \& Skaggs, B. C. (1998). "Relationships and unethical behavior: A social network perspective," Academy of Management Review, 23(1), 14-31.

Burt, R. S. 1992. Structural holes: The social structure of competition, Cambridge, MA: Harvard University Press.

Bylaws and Code of Ethics (n.d.). Retrieved from http://www.professionalconstructor.org/?page=Bylaws

Carley, K., \& Krackhardt, D. (1990). ”Emergent asymmetries in organizations,” Paper presented at the Social Network Conference, San Diego, CA.

Cheung, S. O., Yiu, K. T., \& Chim, P. S. (2006). How relational are construction contracts?. Journal of Professional Issues in Engineering Education and Practice, 132(1), 4856.

Code of Ethics and Professional Conduct. (n.d.). Retrieved from http://www.pmi.org//media/pmi/documents/public/pdf/ethics/pmi-code-of-ethics.pdf?sc_lang_temp=en

Ehrlich, I., \& Lui, F. T. (1999). "Bureaucratic corruption and endogenous economic growth," Journal of Political Economy, 107(S6), S270-S293.

El Asmar, M., Hanna, A. S., \& Loh, W. Y. (2013). Quantifying performance for the integrated project delivery system as compared to established delivery systems. Journal of Construction Engineering and Management, 139(11), 04013012.

Freeman, L. C., Roeder, D., \& Mulholland, R. R. (1979). Centrality in social networks: II. Experimental results. Social networks, 2(2), 119-141.

Granovetter, M. (1973). "The strength of weak ties," American Journal of Sociology, 78: 13601380. 
Gundlach, G. T., \& Achrol, R. S. (1993). "Governance in exchange: contract law and its alternatives," Journal of Public Policy \& Marketing, 141-155.

Hollingsworth, J. (2016, November 23). It's not just bricks and mortar - construction is a people's business, says Gammon chief. Retrieved from http://www.scmp.com/business/article/2048625/its-not-just-bricks-and-mortar-constructionpeoples-business-says-gammon.

Howell, G. A., Ballard, G., \& Tommelein, I. (2010). Construction engineering-Reinvigorating the discipline. Journal of construction engineering and management, 137(10), 740-744.

Izraeli, D. (1988). "Ethical beliefs and behavior among managers: A cross-cultural perspective," Journal of Business Ethics, 7: 263-271.

Johnson, D.G. (1991). Ethical issues in engineering, Prentice Hall, New Jersey: USA

Joskow, P. L. (1987). "Contract duration and relationship-specific investments: Empirical evidence from coal markets," The American Economic Review, 168-185.

Joskow, P. L. (1990). "The performance of long-term contracts: further evidence from coal markets," The Rand Journal of Economics, 251-274.

Kenny, C. (2009). "Transport construction, corruption and developing countries," Transport Reviews, 29(1), 21-41.

Leffler, K. B., \& Rucker, R. R. (1991). "Transactions Costs and the Efficient Organization of Production: A Study of Timber-Harvesting Contracts,” Journal of Political Economy, 10601087.

Le, Y., Shan, M., Chan, A. P., \& Hu, Y. (2014). "Overview of corruption research in construction," Journal of Management in Engineering, 30(4), 02514001.

Macneil, I. R. (1973). The many futures of contracts. S. Cal. l. Rev., 47, 691.

Martin, M., \& Schinzinger, R. (1996). "Ethics in Engineering”, McGraw-Hill, New York.

Matthews, O., \& Howell, G. A. (2005). Integrated project delivery an example of relational contracting. Lean construction journal, 2(1), 46-61.

McCabe, D. L., \& Trevino, L. K. (1993). "Academic dishonesty: Honor codes and other contextual influences," Journal of Higher Education, 64(5): 522-538.

Moodley, K., Smith, N., \& Preece, C. N. (2008). "Stakeholder matrix for ethical relationships in the construction industry,” Construction Management and Economics, 26(6), 625-632.

Murdoch, J., \& Hughes, W. (2002). Construction contracts: law and management. Routledge.

Murnighan, J. K., \& Brass, D. J. (1991). Intra-organizational coalitions. In M. H. Bazerman, R. J. Lewicki, \& B. H. Sheppard (eds.) Research on negotiation in organizations: 283-306. Greenwich, CT: JAI Press.

Pilvang, C., Sutherland, I. (1998). "Research Information: Environmental Management in Project Design," Building Research \& Information, The International Journal of Research, Development, Demonstration and Innovation, 26(2), Mar-Apr, 113

Pressman, A. (1997). Professional Practice 101, A Compendium of Business and Management Strategies in Architecture, John Wiley and Sons, USA

Ritchey, D. (1990). "Bonded by trust: a new construction ethics committee is formed," Arkansas Business and Economic Review, 7(7), 26 Mar, 50.

Scott, J. (1991). Social network analysis: A handbook, London: Sage.

Swierczek, F. W. (1994). "Culture and conflict in joint ventures in Asia," International Journal of Project Management, 12(1), 39-47.

Snaith, M. S., and M. U. Khan.(2008) "Deleterious effects of corruption in the roads sector." Proceedings of the Institution of Civil Engineers-Transport. Vol. 161. No. 4. Thomas Telford Ltd. 
Sohail, M., \& Cavill, S. (2008). "Accountability to prevent corruption in construction projects," Journal of Construction Engineering and Management, 134(9), 729-738.

Tabish, S. Z. S., \& Jha, K. N. (2011). "Analyses and evaluation of irregularities in public procurement in India,” Construction Management and Economics, 29(3), 261-274.

Thomsen, C., Darrington, J., Dunne, D., and Lichtig, W.(2010). "Managing integrated project delivery." White paper of the Construction Management Association of America. McLean, VA, USA 52pp.

Transparency International. (2002). "Bribe payers index 2002." 〈http://archive.transparency.org/policy_research/surveys_indices/bpi/bpi_2002〉(Nov. 12, 2017).

Transparency International. (2006). "Bribe payers index 2006." 〈http://archive.transparency.org/policy_research/surveys_indices/bpi/bpi_2006〉(Nov. 12, 2017).

Transparency International. (2008). "Bribe payers index 2008." 〈http://archive.transparency.org/policy_research/surveys_indices/bpi/bpi_2008〉(Nov. 12, 2017).

Transparency International. (2011). "Bribe payers index 2011." $\langle$ http://bpi.transparency.org/bpi2011/〉(Nov. 12, 2017)

Vee, C., \& Skitmore, C. (2003). "Professional ethics in the construction industry," Engineering, Construction and Architectural Management, 10(2), 117-127.

Williamson, O. E. (1979). Transaction-cost economics: the governance of contractual relations. The journal of Law and Economics, 22(2), 233-261.

Zarkada-Fraser, A., \& Skitmore, M. (2000). Decisions with moral content: collusion. Construction Management \& Economics, 18(1), 101-111.

Zey-Ferrell, M., \& Ferrell, 0. C. (1982). "Role set configuration and opportunity as predictors of unethical behavior in organizations," Human Relations, 35: 587-604.

Zey-Ferrell, M., Weaver, K. M., \& Ferrell, O. C. (1979). Predicting unethical behavior among marketing practitioners. Human Relations, 32: 557-569. 